\title{
Epidemiology of Genotype 1 and 2 Hepatitis E Virus Infections
}

\author{
Kenrad E. Nelson, ${ }^{1}$ Alain B. Labrique, ${ }^{2}$ and Brittany L. Kmush $^{3}$ \\ ${ }^{1}$ Department of Epidemiology, Bloomberg School of Public Health, Johns Hopkins University, Baltimore, \\ Maryland 21205 \\ ${ }^{2}$ Department of International Health, Bloomberg School of Public Health, Johns Hopkins University, Baltimore, \\ Maryland 21205 \\ ${ }^{3}$ Department of Public Health, Food Studies, and Nutrition, Falk College of Sport and Human Dynamics, \\ Syracuse University, Syracuse, New York 13244 \\ Correspondence: knelson3@jhu.edu
}

\begin{abstract}
Hepatitis E virus (HEV) genotypes 1 and 2 are responsible for the majority of acute viral hepatitis infections in endemic areas in South Asia and sub-Saharan Africa. In addition to frequent sporadic illnesses throughout the year, these viruses often cause large epidemics in association with monsoon rains in Asia or during humanitarian crises in Africa. Clinical hepatitis commonly involves adults more often than young children, with an overall mortality of $\sim 1 \%$. However, the mortality among pregnant women is often $30 \%$ or higher. HEV infection in pregnant women frequently leads to infant mortality or premature delivery. Hepatitis $\mathrm{E}$ is an important, yet largely neglected, global public health problem.
\end{abstract}

Fpidemics of jaundice have been recognized Efor several centuries. They have often occurred during military campaigns or after environmental disasters, such as monsoon rains, floods, or earthquakes. In the early 20th century, it was hypothesized that these outbreaks might be the result of a virus, which was transmitted directly from person-to-person or by contaminated water (McDonald 1908; Findlay and Dunlop 1931). Many of these outbreaks, particularly the smaller ones, may have been the result of hepatitis A. However, a large waterborne outbreak occurred in Delhi, India, in December 1955 , which resulted in more than 29,000 reported cases of hepatitis (Viswanathan 1957). Several epidemiologic features of this outbreak differed from those common in sporadic hepatitis cases. First, this large epidemic declined abruptly without evidence that secondary person-to-person spread of infections among household contacts was common. Second, there were 266 deaths, resulting in an overall mortality of $\sim 1 \%$, but 102 deaths occurred in pregnant women who had a mortality rate of $>20 \%$ (Nai$\mathrm{du}$ and Viswanathan 1957). These unusual epidemiologic features of the India outbreak led some infectious disease experts to postulate that the infectious agent responsible for the epidemic was different from that causing sporadic cases of hepatitis. Another similar outbreak occurred in Kashmir in 1978, leading the investigators to question whether the epidemic might

Editors: Stanley M. Lemon and Christopher Walker

Additional Perspectives on Enteric Hepatitis Viruses available at www.perspectivesinmedicine.org

Copyright (C) 2019 Cold Spring Harbor Laboratory Press; all rights reserved; doi: 10.1101/cshperspect.a031732

Cite this article as Cold Spring Harb Perspect Med 2019;9:a031732 
K.E. Nelson et al.

be caused by a novel hepatitis virus (Khuroo et al. 1983). Additionally, a liver specialist in California described up to four separate attacks of acute hepatitis in several hospitalized patients, further confirming the probable existence of multiple human hepatitis viruses (Mosley et al. 1977).

After hepatitis A virus (HAV) was identified by immune electron microscopy in 1973 (Feinstone et al. 1973), researchers tested stored sera collected from convalescent patients involved in the 1955 outbreak in Delhi and found no evidence of HAV infection (Wong et al. 1980). The novel syndrome was called enterically transmitted non-A/non-B (ET-NANB) hepatitis. Subsequently, while investigating an outbreak with similar epidemiologic features in Afghanistan, Mikhail Balayan, using immune electron microscopy, detected $27-30 \mathrm{~nm}$ viral particles in his own stool 4 weeks after ingesting filtered feces from nine patients with ET-NANB characteristics (Balayan et al. 1983). The virus was shown to be distinct from HAV and infectious for cynomolgus monkeys, in which it recapitulated the disease. A similar ET-NANB isolate from Burma was molecularly cloned and sequenced, and found to be a single-stranded, positive-sense RNA virus with a genomic organization resembling that of caliciviruses (Tam et al. 1991). However, the nucleotide sequence of the virus is sufficiently different to warrant its classification within a separate virus family, the Hepeviridae (Smith et al. 2014).

\section{GEOGRAPHIC DISTRIBUTION OF HEPATITIS E VIRUS (HEV) GENOTYPES}

Thus far, five genotypes that are pathogenic for humans have been identified. Genotype (gt) 1 and gt 2 are pathogenic only for humans, whereas gt 3 and gt 4 have animal reservoirs in swine, deer, wild boars, and rabbits. gt7 is the most recently identified human pathogenic genotype and has a reservoir in camels (Lee et al. 2016). It was found to be responsible for a single human infection in a camel owner who had received a liver transplant and lived in the United Arab Emirates. gtl strains are present in the Indian subcontinent, China, Bangladesh, Nepal, Paki- stan, Afghanistan, and most countries in sub-Saharan Africa. gt2 strains are present in Mexico, Nigeria, Chad, Sudan, and the Central African Republic, whereas gt3 strains are present in Europe, the United States, and other North American countries, Central and Southern Japan, New Zealand, and Australia. gt4 HEV is found in China, northern Japan, and India (Fig. 1). gt7 has only been identified in the United Arab Emirates but little research into the geographic distribution of this genotype has been completed.

\section{CLINICAL FEATURES OF HEV INFECTIONS}

Acute hepatitis $\mathrm{E}$ has an incubation period of 3-8 weeks (Labrique et al. 2010a). There is a short prodromal period, followed by jaundice and abdominal discomfort lasting for a few days to several weeks. The majority of infected individuals are asymptomatic but have elevated serum liver enzyme activities. A prospective study in rural Bangladesh found that only $20 \%$ of infections identified prospectively were symptomatic (Labrique et al. 2010b). The proportion of infections that are subclinical may be even higher in persons infected with gt 3 or gt 4 viruses. In addition to acute infection, subjects who are significantly immunocompromised, such as solid-organ transplant recipients receiving immunosuppressive drugs to prevent rejection of the transplant, may develop chronic infection. Chronic gt1 or gt $2 \mathrm{HEV}$ infections have not been reported to date, however.

Fulminant hepatitis among pregnant women has been a common feature of epidemics of hepatitis because of gt $1 \mathrm{HEV}$. Although severe or fulminant hepatitis in pregnancy has not been reported with gt 3 or gt 4 infections, a recently published review reported two cases of fulminant hepatitis among nine pregnant women with autochthonous HEV infections in developed countries (Lachish et al. 2015). Fulminant hepatitis has been commonly seen in pregnant women who acquired the infection in countries endemic for gt $1 \mathrm{HEV}$ and then immigrated to developed countries (Zaaijer et al. 1993; Lachish et al. 2015).

Rarely, patients with acute HEV infection may develop extrahepatic manifestations such 


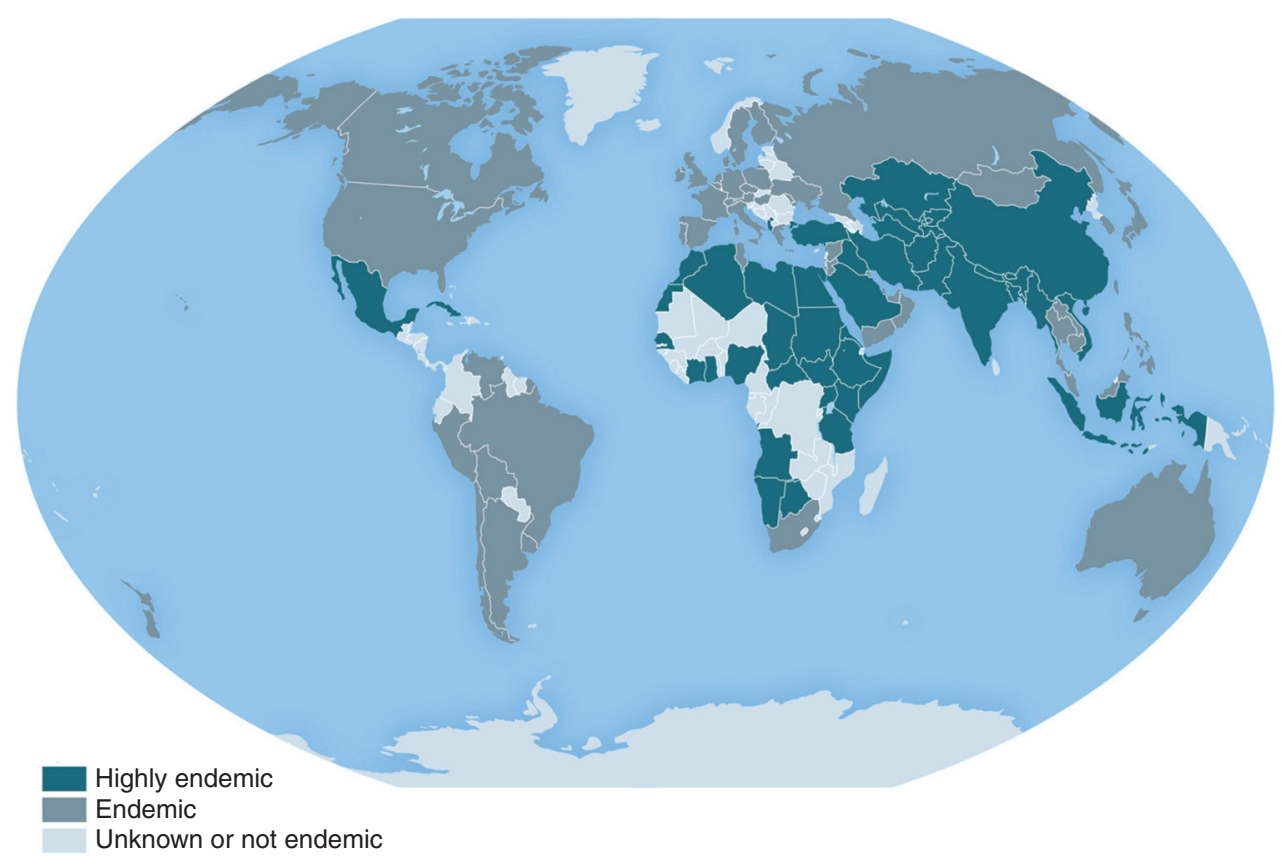

Figure 1. Geographic variation in levels of endemicity for hepatitis E virus (HEV). (Modified figure is taken from the U.S. Centers for Disease Control and Prevention; see wwwnc.cdc.gov/travel/yellowbook/2018/infectiousdiseases-related-to-travel/hepatitis-e.)

as neuritis, Guillain-Barré syndrome, glomerulonephritis, or aplastic anemia (Mishra et al. 1999; Aggarwal 2011; Haffar et al. 2015). Such extrahepatic disease, especially neurological involvement, may be less frequent with gt1 or g2 HEV than with gt3 infections (Dalton et al. 2016). Three case-control studies have shown a significant association between HEV infection and Guillain-Barré syndrome. These were performed in Holland (van den Berg et al. 2014), Bangladesh (Geurtsvankessel et al. 2013), and Japan (Fukae et al. 2016).

\section{THE GLOBAL BURDEN OF GENOTYPE 1 AND 2 HEV}

A study was published in 2012, which estimated the global burden of infections with HEV gt1 and gt2 in 2005 (Rein et al. 2012). These investigators estimated that 20.1 million incident infections (95\% confidence interval [CI]: 2.837.0 ) occurred in the nine regions of the world in which gt 1 and gt 2 are endemic, resulting in
3.4 (95\% CI: 0.5-6.5) million symptomatic cases, 70,000 (95\% CI: 12,400-132,732) deaths, and 3000 (95\% CI: 1892-4424) stillbirths. An independent analysis of the global burden of viral hepatitis from 1990 to 2013 was published in 2016 (Stanaway et al. 2016). This study estimated there had been a $63 \%$ increase in mortality attributable to viral hepatitis between 1990 and 2012, primarily as a result of increasing population size. The mortality attributed to HEV was estimated to have declined during the period related to improvements in sanitation in several low-income endemic countries. The incidence of HEV gt 1 and gt 2 infection was estimated to peak between ages 15 and 30 (Fig. 2) (Rein et al. 2012).

\section{HEV GENOTYPE 1}

Outbreaks of disease caused by HEV gt1 strains are almost always a result of waterborne transmission of the virus. Large outbreaks have been commonly reported in India, Pakistan, Nepal, 
K.E. Nelson et al.

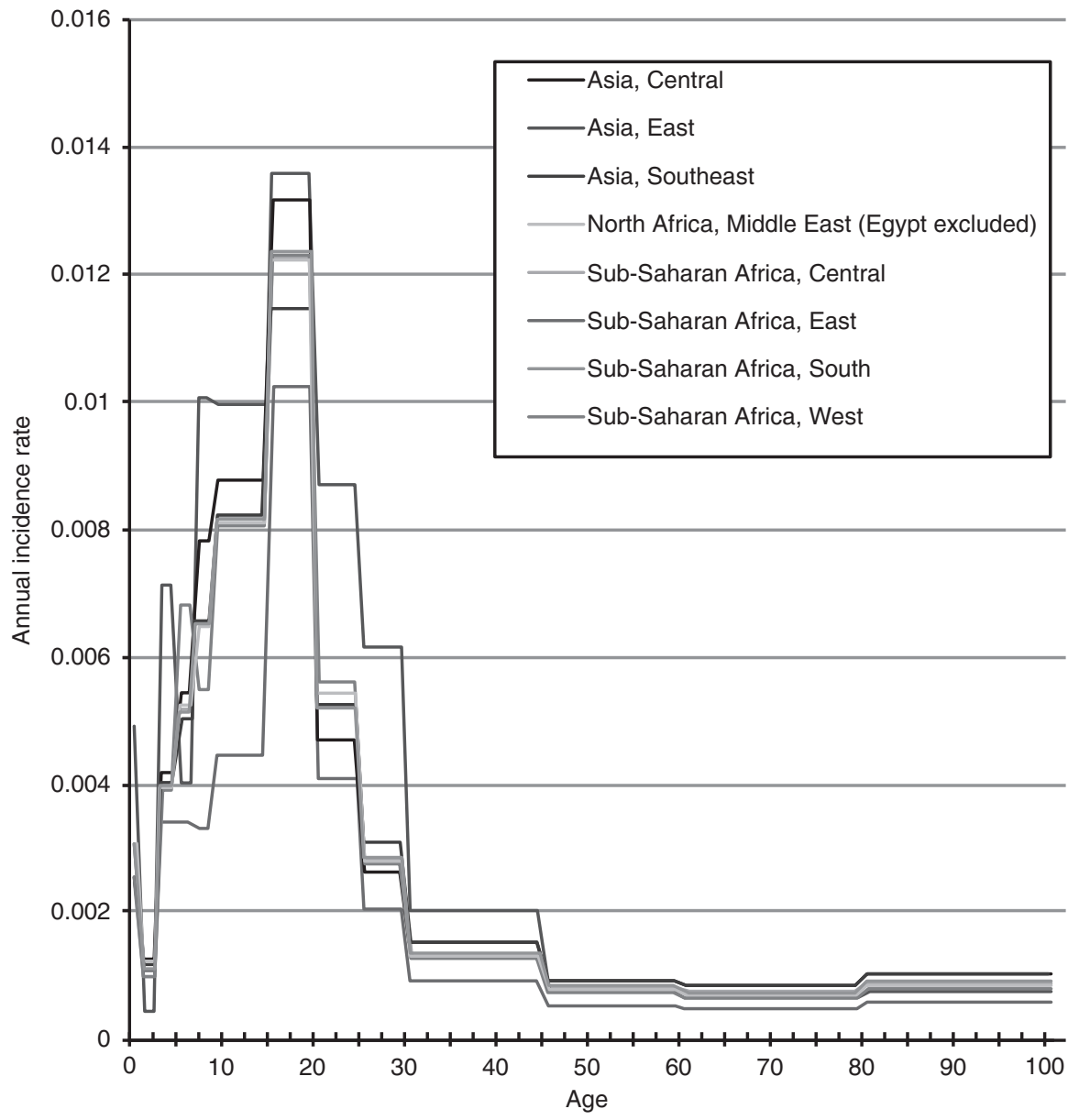

Figure 2. Estimated incidence of hepatitis E virus (HEV) by age and global burden of disease region in 2005. (From Rein et al. 2012; reprinted, with permission, from John Wiley and Sons (c) 2012.)

Bangladesh, and other South Asian countries (Table 1). However, the largest recorded outbreak occurred between 1986 and 1988, with 120,000 reported cases and 765 deaths, of which 51 were in pregnant women (Wang 1989). Following the outbreak in Delhi in 1955, India experienced frequent outbreaks affecting hundreds or thousands of people, particularly between 1975 and 1994. The largest outbreak in India occurred in Kanpur from December 1990 to April 1991 and involved 79,000 cases of clinical hepatitis (Naik et al. 1992). An outbreak in Kashmir, India, in 1978-1979 involved 20,000 people and resulted in 600 deaths, of which 436 were pregnant women (Khuroo 1980). Other Asian countries have also reported outbreaks of HEV, including Pakistan, Indonesia, Myanmar, Vietnam, Japan, China, Bangladesh, Nepal, Iraq, Uzbekistan, and Turkmenistan (Hakim et al. 2017).

HEV outbreaks also have been reported from 14 countries in Africa, including Egypt, Kenya, Sudan, South Sudan, Central African Republic, Uganda, Chad, Republic of Djibouti, Algeria, Namibia, Morocco, Somalia, Ethiopia, South Africa, and Cameroon (Kim et al. 2014). In contrast to the epidemics in Asia, the African epidemics did not occur during monsoon rains but were often linked to contaminated water and humanitarian crises, occurring in refugee camps, during wars, or civil conflicts. Two small gt1 outbreaks were reported from Cuba (de la 
Epidemiology of Genotype 1 and 2 HEV Infections

Table 1. Morbidity and mortality from selected waterborne hepatitis E virus epidemics

\begin{tabular}{llrrr}
\hline & & & Total & Deaths of pregnant \\
Site & \multicolumn{1}{c}{ Years } & Cases & deaths & women \\
\hline Delhi, India & $1954-1955$ & 29,300 & 266 & 102 \\
Bosnia, Yugoslavia & 1964 & 4984 & 98 & 82 \\
Kathmandu, Nepal & 1973 & 10,000 & 118 & 30 \\
Kashmir, India & $1978-1979$ & 20,000 & 600 & 436 \\
Xinjiang, China & $1986-1988$ & 119,280 & 705 & 51 \\
Shebeli, Somalia & $1988-1989$ & 11,413 & 346 & 48 \\
Maharashtra, India & $1989-1990$ & 3580 & 50 & 32 \\
Kanpur, India & 1991 & 70,000 & 48 & 13 \\
Islamabad, Pakistan & $1993-1994$ & 3458 & 8 & 4 \\
Darfur, Sudan & 2004 & 2621 & 45 & 19 \\
Kitgum, Uganda & $2007-2009$ & 4789 & 72 & 13 \\
Nellore, Andhra Pradesh, India & $2008-2009$ & 23,915 & 315 & Unknown \\
Dhaka, Bangladesh & $2008-2009$ & 4751 & 18 & 4 \\
Rajshahi, Bangladesh & 2010 & 2162 & 12 & 3 \\
Ichalkaranji/Kolhapur, Maharashtra, India & 2012 & 5165 & 36 & 5 \\
Refugee Camps, Upper Nile, South Sudan & $2012-2013$ & 10,055 & 214 & 2 \\
Biratnagar, Morang, Nepal & 2014 & 7000 & 17 & 12 \\
Raipur, Chhattisgarh, India & 2014 & 5000 & 31 & 18 \\
Napak, Karamoja, Uganda & $2013-2014$ & 1498 & 32 & 2 \\
Sambalpur, Odisha, India & $2014-2015$ & 3000 & 50 & 2 \\
Refugee Camps, Gambella, Ethiopia & $2014-2015$ & 1117 & 21 & Unknown \\
Shimla/Solan, Himachal Pradesh, India & $2015-2016$ & $5000-10,000$ & 22 & 21 \\
Beria, South Sudan & $2015-2016$ & 2475 & 21 & \\
\hline
\end{tabular}

Data from Teo 2012; reprinted, with permission, from Cambridge University Press @ 2018, and Nelson et al. 2016; reprinted, with permission, from Wolters Kluwer Health @ 2016, respectively.

Caridad Montalvo Villalba et al. 2008). Although no outbreaks of HEV have occurred in the United States or Western Europe in the 20th or 21 st centuries, many outbreaks of acute jaundice with high mortality in pregnant women were reported in the 19th century (Teo 2012). Apparently, improved sanitation and water treatment has eliminated HEV gt1 waterborne outbreaks in the United States and Europe during the 20th century.

During most of these outbreaks, there was no evidence of frequent person-to-person transmission. Often, only single cases were reported in a household, or multiple cases occurred simultaneously. However, in an outbreak in Uganda between October 2007 and August 2009, $2531(78.6 \%)$ of 3218 cases lived in a household with more than one case (Teshale et al. 2010). In the households with multiple cases, 616 secondary cases $(24.9 \%)$ occurred more than 8 weeks after the index case in the household. Because the investigators were unable to identify HEV RNA in water supplies from households with multiple cases, they believed secondary cases were likely to have been transmitted from the index case. The epidemic persisted for $>18$ months, and the researchers concluded there was significant secondary person-to-person spread. Nonetheless, although the evidence supports the probability of some person-to-person spread of infection in this outbreak, the majority of infections appear to have been waterborne (Aggarwal and Gandhi 2010).

Although large epidemics of waterborne HEV have been reported frequently, endemic transmission during the dry season is also common in countries with recurring epidemics, when the levels of water contamination can increase. Many of the outbreaks in India, Nepal, and Bangladesh occurred during or immediately following monsoon rains. However, outbreaks are also associated with broken water pipelines, 
K.E. Nelson et al.

use of untreated water from rivers or shallow wells for drinking, failure of water treatment plants, and inadequate chlorination of the water supply (Hakim et al. 2017). A large commercial laboratory in Dhaka, Bangladesh has found HEV infection to be the most frequent etiology of clinical hepatitis throughout the year (Sazzad et al. 2017). Surveillance of patients with acute jaundice in Northern Uganda has found most cases to be from HEV infection throughout the year (Gerbi et al. 2015). Persistent continuous transmission may be necessary to maintain a human reservoir of gt1 HEV between large outbreaks in endemic countries.

\section{HEV GENOTYPE 2}

The first outbreaks of HEV gt2 infection were recognized in Huitzililla and Telixtac, Mexico, in late 1986 (Velazquez et al. 1990). The first outbreak began in June, 1 month after the start of the rainy season. It resulted in 94 icteric cases and two deaths in women. This outbreak lasted 3 months. The second outbreak of 129 cases among 2194 inhabitants in Telixtac began in August 1986, about 3 months after the rainy season. One death occurred in a nonpregnant woman; another pregnant woman was ill but recovered. However, her 3-month-old infant died of unknown causes. The investigators studying this outbreak identified $32-34 \mathrm{~nm}$ viral particles in samples of stool from cases using immune electron microscopy. The genome of the Mexican virus was molecularly cloned and sequenced; it was found to have $76 \%$ nucleic acid identity overall with the Burma isolate and was therefore classified in a distinct genotype, HEV gt2 (Huang et al. 1992).

A waterborne outbreak of hepatitis E affecting >600 people was reported in 1995 in Namibia (Maila et al. 2004). This strain was virtually identical to the HEV gt2 virus from Mexico. Another outbreak occurred in 2004 in several refugee camps in Sudan and Chad. HEV isolates from this outbreak were genetically heterogeneous; 23 isolates from Sudan and five viruses from Chad clustered with gt1 strains, but four isolates were similar to gt 2 strains from Mexico (Nicand et al. 2005). The epidemiology and clin- ical features of gt1 and two viruses appeared to be quite similar. Other gt 2 strains have been isolated from patients in Nigeria (Buisson et al. 2000) and the Central African Republic (Escriba et al. 2008). A reference sequence derived from the HEV gt2 isolate (Mex-14) from Mexico has been published recently (Genbank KX578717) (Kaiser et al. 2017).

\section{RISK FACTORS FOR HEV GENOTYPE 1 AND 2 INFECTIONS}

During community-wide outbreaks of HEV, the incidence is highest in adolescents and adults in the second through the fourth decades of life. Young children under age 10 have lower rates of infection and clinical illness (Figs. 2 and 3) (Rein et al. 2012). The reasons for the sparing of young children are not understood. However, it is possible that children consume less contaminated water, and thus may be exposed to HEV below the infectious dose. Recent evidence from Bangladesh suggests that children infected with HEV may lose detectable antibodies more quickly than adults, complicating the interpretation of cross-sectional studies of antibody prevalence (Kmush et al. 2016).

Most epidemiological studies of HEV have been performed during or following outbreaks, therefore risk factors for sporadic infection have not been well studied. To better understand the epidemiology and risk factors for HEV during various seasons and climatic conditions, a prospective study was performed involving a cohort of 1134 randomly selected subjects in a population of 23,500 persons in rural Bangladesh (Labrique et al. 2009, 2010b). At baseline, the HEV seroprevalence was $22.5 \%$. During the first 12 months of follow-up, there were 49 seroconversions indicating an overall incidence density of 60.3 (95\% CI: 44.6-79.7) per 1000 person-years. Of the seroconverters, 33 subjects reported at least one symptom of a hepatitis-like illness and six reported that they were jaundiced. There were no significant differences between seroconverters and controls in household size, location of primary employment, or socioeconomic status. The incidence was lower in individuals under age 10, with an incidence of 28.9 per 1000 


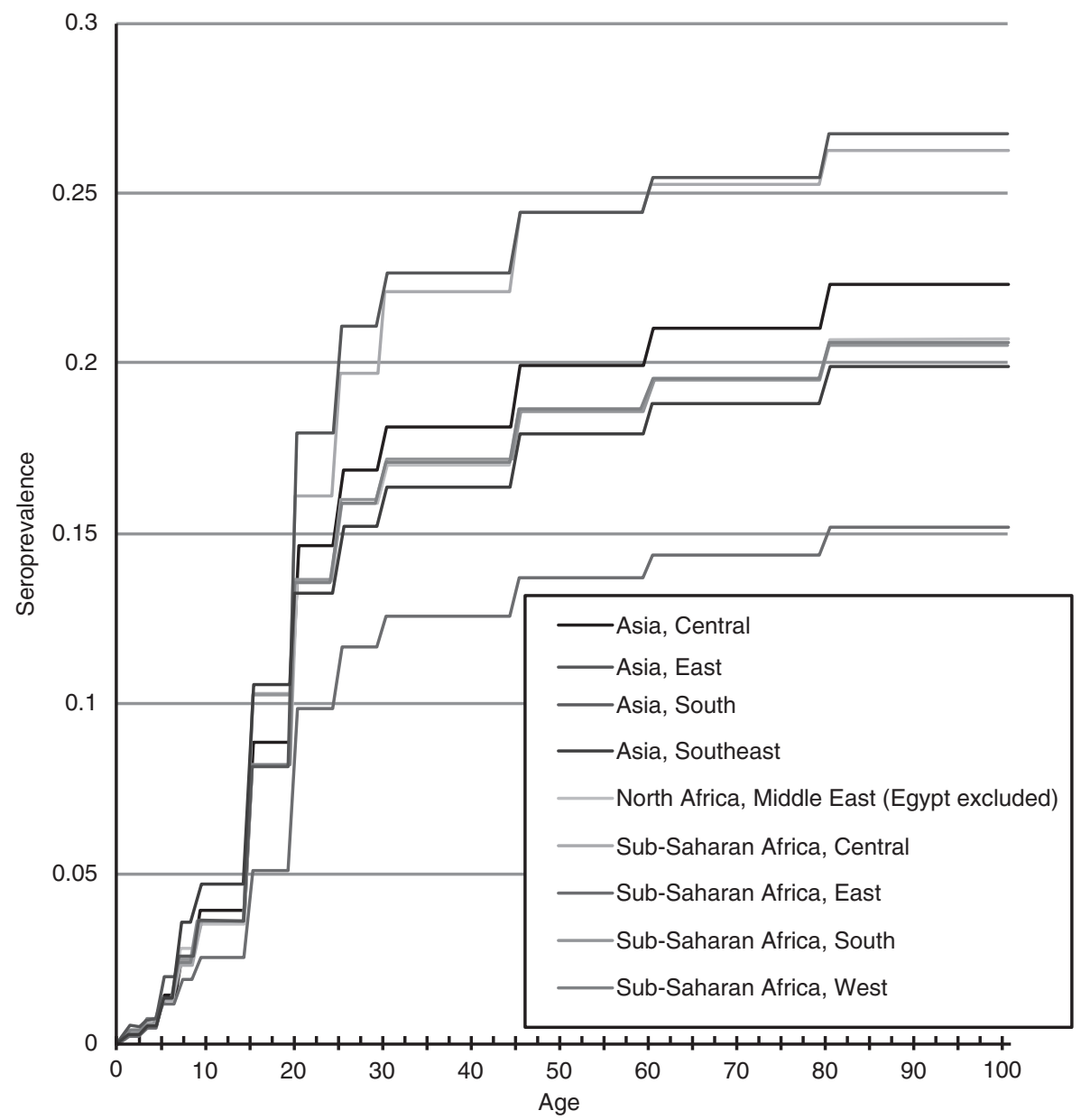

Figure 3. Estimated seroprevalence of hepatitis E virus (HEV) by age and global burden of disease region in 2005. (From Rein et al. 2012; reprinted, with permission, from John Wiley and Sons @ 2012.)

person-years. The incidence was similar among males and females. The subjects were followed for another 6 months for observation during a monsoon season. During this follow-up, another 26 seroconverters were detected for 359 person-years, for an incidence of 72.4 (95\% CI: 47.3, 106.1) per 1000 person-years.

A second prospective study was performed in which a clinical algorithm screening for signs or symptoms of hepatitis, such as abdominal pain, dark urine, jaundice, and clay-colored stools, was used to detect possible HEV infections among a population of 23,500 people who had routine household visits from a trained health worker every 30 days (Labrique et al.
2013). All subjects in the community over the age of 1 year were included in this study. Sera from subjects with symptoms possibly as a result of HEV infection were tested serologically. If HEV infection was confirmed, four agematched controls were selected. Both cases and controls were interviewed to assess risk factors for infection. This study found several risk factors to be significant in a multivariate analysis, including recent exposure to a jaundiced person, travel to a town or city in the last 3 months, unsanitary toilet use, working outside the home, injections in the last 3 months, larger household size, and low household construction score (Table 2). This study suggests there may be multiple 
K.E. Nelson et al.

Table 2. Multivariate conditional logistic regression model of risk factors for HEV disease ${ }^{a}$

\begin{tabular}{|c|c|c|c|c|c|c|}
\hline \multirow[b]{2}{*}{ Characteristic } & \multicolumn{3}{|c|}{ Manual (forced) model ${ }^{b}$} & \multicolumn{3}{|c|}{ Stepwise selected model ${ }^{\mathrm{C}}$} \\
\hline & OR & $95 \% \mathrm{Cl}$ & $p$ Value & OR & $95 \% \mathrm{Cl}$ & $p$ Value \\
\hline Gender $(0=\text { male, } 1=\text { female })^{\mathrm{d}}$ & 0.30 & $0.07-1.20$ & 0.088 & - & - & - \\
\hline Recent exposure to "jaundice" patient & 63.50 & $8.07-499.50$ & $<0.000$ & 82.50 & $8.77-776.39$ & $<0.000$ \\
\hline Travel to town/city in the past 3 months & 2.80 & $0.78-10.08$ & 0.114 & 4.25 & $1.06-17.10$ & 0.041 \\
\hline Unsanitary toilet use & 4.39 & $1.02-18.98$ & 0.048 & 5.14 & $1.20-22.01$ & 0.027 \\
\hline Work outside the home & 19.36 & $1.39-269.75$ & 0.027 & 19.80 & $1.89-207.96$ & 0.013 \\
\hline Outdoor work (farming/fishing/labor) & 4.17 & $0.73-23.78$ & 0.108 & 8.63 & $1.33-56.09$ & 0.024 \\
\hline Injection in the last 3 months & 18.44 & $2.10-162.05$ & 0.009 & 15.50 & $1.97-121.76$ & 0.009 \\
\hline Household size ( $\leq 4,5-6, \geq 7$ members $)$ & 0.49 & $0.29-0.84$ & 0.009 & 0.17 & $0.05-0.56$ & 0.004 \\
\hline Household construction score (1-6) & - & - & - & 0.35 & $0.13-0.98$ & 0.045 \\
\hline
\end{tabular}

Table reproduced from Labrique et al. 2013, courtesy of the Creative Commons Attribution License (c) 2013.

${ }^{a}$ Only the models constructed using the liberal case definition are shown as the conservative case definition was extremely restricted by a low sample size.

${ }^{\mathrm{b}}$ Model reflects explanatory variables of interest significant at the $25 \%$ level $(p<0.25)$ in univariate conditional logistic regression and retained at least $15 \%(p<0.15)$ significance in the multiple, adjusted model.

${ }^{\mathrm{c}}$ Model selected by forward and reverse stepwise conditional logistic regression, including variables significant at the $25 \%$ level $(p<0.25)$ in univariate analysis and retained in the final mode if significant at the $10 \%(p<0.10)$ level.

${ }^{\mathrm{d}}$ Gender was left out of the stepwise model as female gender was strongly inversely correlated with work outside the home or with performing outdoor work. Stratified analysis was not possible or appropriate because of extremely small numbers in each cell.

sources of person-to-person transmission in a low-resource rural community in a country with frequent, large rainy season epidemics.

A prospective study of 757 healthy army soldiers and police officers was performed in the Kathmandu Valley of Nepal in March to September 1992 and September 1993 (Clayson et al. 1997). At baseline, 186 (24.6\%) of the subjects were anti-HEV immunoglobulin (Ig)G-positive. During the 6 months between March and September 1992, 19 persons seroconverted. Four of the 19 were jaundiced. During the 12 months between September 1992 and September 1993 another 35 people were infected. The incidence was highest in younger subjects, aged 12-19 years. The overall incidence of infection was 64 per 1000 person-years. The incidence of disease was 20 per 1000 person-years.

Another prospective study was performed in two villages in Egypt. The baseline prevalence of anti-HEV antibody was $67.7 \%$. The study enrolled 919 villagers who were seronegative for HEV. Thirty-four seroconverters were identified indicating an incidence of HEV infection of 41.6 per 1000 person-years. All seroconverters were asymptomatic. There was no association between seroconversion and socioeconomic factors, source of water, sanitation, hand and vegetable washing, or other environmental variables (Stoszek et al. 2006b). Both gt1 and gt3 HEV have been identified in Egypt, but gt1 strains are more frequent.

The reasons for the differences evident in the clinical and epidemiologic characteristics of acute $\mathrm{HEV}$ infections in Egyptian versus South Asian populations are not known. Young children have high seroprevalence of antibodies to HEV in Egypt (Kamel et al. 1995; Darwish et al. 1996; Fix et al. 2000), and asymptomatic HEV infections are common among adults, including pregnant women (Stoszek et al. 2006a), in contrast to South Asian populations. Monsoon rains with flooding do not occur in Egypt. However, exposure to water that is highly contaminated with HEV may be common in early life. It has been theorized that most adult infections in Egypt occur in people who had a primary infection in childhood and in whom antibodies are no longer detectable, and who clear a second infection later in life without developing symptoms by activating an immune memory response (Stoszek et al. 2006b). 


\section{RACE AND SUSCEPTIBILITY TO HEV INFECTION}

Within the United States, blacks appear to have lower rates of HEV infection. The prevalence of anti-HEV IgG (caused presumably by previous gt 3 or gt 4 infection) in the National Health and Nutrition Study (NHANES) was $15.3 \%$ in nonHispanic blacks, $22.3 \%$ in non-Hispanic whites, and $21.8 \%$ in Mexican-Americans (Kuniholm et al. 2009). Among non-Hispanic blacks, the anti-HEV IgG seroprevalence was lower in people with certain polymorphisms in the geneencoding apolipoprotein E gene (APOE), a protein that mediates lipoprotein metabolism. HEV seropositivity was significantly lower in subjects carrying the APOE $\varepsilon 4$ allele (odds ratio 0.5, 95\% CI: 0.4-0.7) compared with those with the APOE\&2 allele (Zhang et al. 2015). Also, in South Africa, where gt 1 virus has been endemic, the prevalence of anti-HEV IgG was lower in black blood donors in South Africa than in white or mixed-race donors (Lopes et al. 2017).

\section{HEPATITIS E IN PREGNANCY}

High maternal and fetal morbidity and mortality are characteristic epidemiologic features of HEV gt1 infections in pregnant women. The pathogenesis of these more severe infections in pregnant women is not well understood. Severe or fatal infections are more common in late pregnancy, during the second or third trimesters.

One explanation that has been proposed for the more severe disease in pregnant women is the shift that occurs in the predominant immune response from a T-helper cell type 1 (Th1) to a Th2-dominated response in late pregnancy to protect the fetus by suppressing macrophage activation (Romagnani 1997). Changes in immunologic responses develop gradually throughout pregnancy and vary with increased estradiol and progesterone levels as the pregnancy progresses toward term (Robinson and Klein 2012; Krain et al. 2014). The somewhat immunocompromised status of women in late pregnancy could inhibit the development of an immune response capable of controlling an acute HEV infection (Krain et al. 2014).
Epidemiology of Genotype 1 and 2 HEV Infections

However, other factors may contribute to the increased severity of HEV among pregnant women and their infants. Nutritional deficiencies exacerbated by increased nutritional requirements to sustain a pregnancy could contribute to more severe disease in late pregnancy (Kumar et al. 2017). A study of 144 pregnant women with HEV hepatitis found lower levels of pre-albumin, folate, and lower body mass index, and upper arm skinfold thickness than healthy controls (Kumar et al. 2017). Deficiencies in zinc, vitamin $\mathrm{D}$, and anemia have been associated with an increased incidence of HEV infections in populations in rural Bangladesh (Kmush et al. 2016). Also, HEV infections have been associated with elevated levels of arsenic among pregnant women in Bangladesh (Heaney et al. 2015).

Pregnant women commonly develop hepatic cholestasis ("fatty liver") as a complication of their pregnancy (Wong et al. 2008). This could result in a type of "acute on chronic" liver disease with more severe outcomes, when women are infected from waterborne HEV during late pregnancy. The status of pregnant women who develop fulminant $\mathrm{HEV}$ in comparison with those who control an HEV infection has not been well characterized prospectively, although a Th2 immune response to HEV infection has been well documented among pregnant women, as alluded to above (Pal et al. 2005; Krain et al. 2014).

Severe or fatal cases of HEV among pregnant women may present with fulminant hepatic failure (FHF), bleeding, eclampsia, or disseminated intravascular coagulation (Khuroo and Kamili 2003; Jilani et al. 2007; Patra et al. 2007). It has been hypothesized that pregnant women may have an increased viral load related to replication of HEV in the infant or the placenta (Khuroo and Kamili 2003; Bose et al. 2014). Pregnant women with FHF have been found to have higher viral loads than those with uncomplicated acute hepatitis (Kar et al. 2008). However, another study in India found higher serum viral loads in patients with acute hepatitis who survived than in those with fulminant hepatitis (Saravanabalaji et al. 2009). The interpretation of these reports is made difficult by the fact that the viral load could be reduced if 
K.E. Nelson et al.

measured after severe liver disease has resulted in hepatic necrosis with declines in the production of virus. As a contributing factor, the HEV ORF3 protein has been suggested to interfere with the normal coagulation process, leading to hemorrhage during pregnancy (Geng et al. 2013).

Additional research to understand the immunopathogenesis of fulminant hepatitis in pregnant women infected with HEV should be a high priority. Two studies indicated that $9 \%-$ $20 \%$ of maternal mortality in Bangladesh was accompanied by jaundice, likely reflecting HEV infection (Labrique et al. 2012; Shah et al. 2016) and further emphasizing the public health importance of gt 1 and gt $2 \mathrm{HEV}$. There is also a need to understand risk factors for severe disease. One study found activation of both Th1 and Th2 cytokines before HEV infection in pregnant women. However, none of the women studied developed fulminant hepatitis (Kmush et al. 2016).

\section{PREVENTION AND TREATMENT}

Prevention of gt 1 and gt $2 \mathrm{HEV}$ infections is very difficult because of constraints on resources in which HEV is endemic. Water from rivers or surface water often contains high levels of microbial contamination. Deep tube wells can provide access to water that is free of contamination. However, tube wells often contain dangerous levels of arsenic, especially in Northern India and Bangladesh (Smith et al. 2000). Boiling water before drinking will inactivate $\mathrm{HEV}$ and other pathogens but is often impractical for daily use in low-resource countries. Chlorination also inactivates HEV and is often effective at slowing outbreaks (Girones et al. 2014; Guerrero-Latorre et al. 2016). However, a program to add chlorine to drinking water during an outbreak in Darfur, Sudan, in 2004 failed to prevent new HEV infections (Guthmann et al. 2006).

The use of an HEV vaccine to prevent $\mathrm{HEV}$ in high-risk populations is a more promising strategy. Two subunit vaccines have undergone phase 3 trials and been found to be effective (Shrestha et al. 2007; Zhu et al. 2010). However, only one vaccine has been licensed for use and it is only available in China (see Innis and Lynch
2018). This subunit vaccine is given in three doses at 0,1 , and 6 months and was found to be $86.8 \%$ ( $95 \%$ CI: $71 \%$ to $94 \%$ ) effective in preventing infection 4.5 years after vaccination (Zhang et al. 2015). Additional research is needed to determine the efficacy of this vaccine in high-risk populations, especially pregnant women, using accelerated vaccine schedules suitable for outbreak situations (Nelson et al. 2014).

Ribavirin treatment of chronic HEV infections in transplant patients has been effective (Kamar et al. 2015). However, ribavirin treatment of pregnant women or other patients with fulminant hepatitis has not been reported. Although ribavirin is generally contraindicated in pregnant women because of the risk of teratogenicity, it might be relatively safe in pregnancies in the third trimester because the infant's organs have already developed. However, a riskbenefit analysis of ribavirin treatment in the third trimester of pregnancy is needed. Additionally, ribavirin is not likely to be as effective in controlling the immunopathology associated with HEV in pregnancy with severe or fulminant hepatitis as it has been in treating chronic infections in transplant patients. Better methods are needed to prevent and treat gt 1 and gt $2 \mathrm{HEV}$ infections, especially in low-resource settings.

\section{REFERENCES}

${ }^{*}$ Reference is also in this collection.

Aggarwal R. 2011. Clinical presentation of hepatitis E. Virus Res 161: 15-22.

Aggarwal R, Gandhi S. 2010. The global prevalence of hepatitis E virus infection and susceptibility: A systematic review. World Health Organization, Geneva.

Balayan MS, Andjaparidze AG, Savinskaya SS, Ketiladze ES, Braginsky DM, Savinov AP, Poleschuk VF. 1983. Evidence for a virus in non-A, non-B hepatitis transmitted via the fecal-oral route. Intervirology 20: 23-31.

Bose PD, Das BC, Hazam RK, Kumar A, Medhi S, Kar P. 2014. Evidence of extrahepatic replication of hepatitis E virus in human placenta. J Gen Virol 95: 1266-1271.

Buisson Y, Grandadam M, Nicand E, Cheval P, van CuyckGandre H, Innis B, Rehel P, Coursaget P, Teyssou R, Tsarev S. 2000. Identification of a novel hepatitis E virus in Nigeria. J Gen Virol 81: 903-909.

Clayson ET, Shrestha MP, Vaughn DW, Snitbhan R, Shrestha KB, Longer CF, Innis BL. 1997. Rates of hepatitis E 
virus infection and disease among adolescents and adults in Kathmandu, Nepal. J Infect Dis 176: 763-766.

Dalton HR, Kamar N, van Eijk JJ, Mclean BN, Cintas P, Bendall RP, Jacobs BC. 2016. Hepatitis E virus and neurological injury. Nat Rev Neurol 12: 77-85.

Darwish MA, Faris R, Clemens JD, Rao MR, Edelman R 1996. High seroprevalence of hepatitis A, B, C, and E viruses in residents in an Egyptian village in The Nile Delta: A pilot study. Am J Trop Med Hyg 54: 554-558

de la Caridad Montalvo Villalba M, de los Angeles Rodríguez Lay L, Chandra V, Corredor MB, Frometa SS, Moreno AG, Jameel S. 2008. Hepatitis E virus genotype 1, Cuba. Emerg Infect Dis 14: 1320-1322.

Escriba JM, Nakoune E, Recio C, Massamba PM, MatsikaClaquin M, Goumba C, Rose AM, Nicand E, Garcia E, Leklegban C, et al. 2008. Hepatitis E, Central African Republic. Emerg Infect Dis 14: 681-683.

Feinstone SM, Kapikian AZ, Purcell RH. 1973. Hepatitis A: Detection by immune electron microscopy of a virus-like antigen associated with acute illness. Science 182: 10261028.

Findlay GM, Dunlop JL. 1931. Observations on an epidemic of catarrhal jaundice. Trans R Soc Trop Med Hyg 25: 7-28.

Fix AD, Abdel-Hamid M, Purcell RH, Shehata MH, AbdelAziz F, Mikhail N, el Sebai H, Nafeh M, Habib M, Arthur RR, et al. 2000. Prevalence of antibodies to hepatitis $\mathrm{E}$ in two rural Egyptian communities. Am J Trop Med Hyg 62: 519-523.

Fukae J, Tsugawa J, Ouma S, Umezu T, Kusunoki S, Tsuboi Y. 2016. Guillain-Barré and Miller Fisher syndromes in patients with anti-hepatitis E virus antibody: A hospitalbased survey in Japan. Neurol Sci 37: 1849-1851.

Geng Y, Yang J, Huang W, Harrison TJ, Zhou Y, Wen Z, Wang Y. 2013. Virus host protein interaction network analysis reveals that the HEV ORF3 protein may interrupt the blood coagulation process. PLOS ONE 8: e56320.

Gerbi GB, Williams R, Bakamutumaho B, Liu S, Downing R, Drobeniuc J, Kamili S, Xu F, Holmberg SD, Teshale EH. 2015. Hepatitis $E$ as a cause of acute jaundice syndrome in northern Uganda, 2010-2012. Am J Trop Med Hyg 92: 411-414.

Geurtsvankessel CH, Islam Z, Mohammad QD, Jacobs BC Endtz HP, Osterhaus AD. 2013. Hepatitis E and GuillainBarré syndrome. Clin Infect Dis 57: 1369-1370.

Girones R, Carratala A, Calgua B, Calvo M, RodriguezManzano J, Emerson S. 2014. Chlorine inactivation of hepatitis $\mathrm{E}$ virus and human adenovirus 2 in water. $J$ Water Health 12: 436-442.

Guerrero-Latorre L, Gonzales-Gustavson E, Hundesa A, Sommer R, Rosina G. 2016. UV disinfection and flocculation-chlorination sachets to reduce hepatitis $\mathrm{E}$ virus in drinking water. Int J Hyg Environ Health 219: 405-411.

Guthmann JP, Klovstad H, Boccia D, Hamid N, Pinoges L, Nizou JY, Tatay M, Diaz F, Moren A, Grais RF, et al. 2006. A large outbreak of hepatitis E among a displaced population in Darfur, Sudan, 2004: The role of water treatment methods. Clin Infect Dis 42: 1685-1691.

Haffar S, Bazerbachi F, Lake JR. 2015. HEV-associated cryoglobulinaemia and extrahepatic manifestations of hepatitis E. Lancet Infect Dis 15: 268.
Epidemiology of Genotype 1 and 2 HEV Infections

Hakim MS, Wang W, Bramer WM, Geng J, Huang F, de Man RA, Peppelenbosch MP, Pan Q. 2017. The global burden of hepatitis E outbreaks: A systematic review. Liver Int 37: 19-31.

Heaney CD, Kmush B, Navas-Acien A, Francesconi K, Gossler W, Schulze K, Fairweather D, Mehra S, Nelson KE, Klein SL, et al. 2015. Arsenic exposure and hepatitis E virus infection during pregnancy. Environ Res 142: 273-280.

Huang CC, Nguyen D, Fernandez J, Yun KY, Fry KE, Bradley DW, Tam AW, Reyes GR. 1992. Molecular cloning and sequencing of the Mexico isolate of hepatitis E virus (HEV). Virology 191: 550-558.

* Innis BL, Lynch JA. 2018. Immunization against hepatitis E. Cold Spring Harb Perspect Med doi: 10.1101/cshperspect. a032573.

Jilani N, Das BC, Husain SA, Baweja UK, Chattopadhya D, Gupta RK, Sardana S, Kar P. 2007. Hepatitis E virus infection and fulminant hepatic failure during pregnancy. J Gastroenterol Hepatol 22: 676-682.

Kaiser M, Kamili S, Hayden T, Blümel J, Baylis SA. 2017. Genome sequence of a genotype 2 hepatitis E virus World Health Organization reference strain. Genome Announc 5: $\mathrm{e} 01664$.

Kamar N, Lhomme S, Abravanel F, Cointault O, Esposito L, Cardeau-Desangles I, Del Bello A, Dorr G, Lavayssiere L, Nogier MB, et al. 2015. An early viral response predicts the virological response to ribavirin in hepatitis E virus organ transplant patients. Transplantation 99: $2124-$ 2131.

Kamel MA, Troonen H, Kapprell HP, el-Ayady A, Miller FD. 1995. Seroepidemiology of hepatitis E virus in the Egyptian Nile Delta. J Med Virol 47: 399-403.

Kar P, Jilani N, Husain SA, Pasha ST, Anand R, Rai A, Das BC. 2008. Does hepatitis E viral load and genotypes influence the final outcome of acute liver failure during pregnancy? Am J Gastroenterol 103: 2495-2501.

Khuroo MS. 1980. Study of an epidemic of non-A, non-B hepatitis. Possibility of another human hepatitis virus distinct from post-transfusion non-A, non-B type. Am J Med 68: $818-824$

Khuroo MS, Kamili S. 2003. Aetiology, clinical course and outcome of sporadic acute viral hepatitis in pregnancy. $J$ Viral Hepat 10: 61-69.

Khuroo MS, Duermeyer W, Zargar SA, Ahanger MA, Shah MA. 1983. Acute sporadic non-A, non-B hepatitis in India. Am J Epidemiol 118: 360-364.

Kim J, Nelson KE, Panzner U, Kasture Y, Labrique AB, Wierzba TF. 2014. A systematic review of the epidemiology of hepatitis E virus in Africa. BMC Infect Dis 14: 308.

Kmush BL, Labrique A, Li W, Klein SL, Schulze K, Shaikh S, Ali H, Engle RE, Wu L, Purcell RH, et al. 2016. The association of cytokines and micronutrients with hepatitis $E$ virus infection during pregnancy and the postpartum period in rural Bangladesh. Am J Trop Med Hyg 94: 203211.

Krain LJ, Nelson KE, Labrique AB. 2014. Host immune status and response to hepatitis E virus infection. Clin Microbiol Rev 27: 139-165.

Kumar A, Sharma S, Kar P, Agarwal S, Ramji S, Husain SA, Prasad S, Sharma S. 2017. Impact of maternal nutrition in 
K.E. Nelson et al.

hepatitis E infection in pregnancy. Arch Gynecol Obstet 296: 885-895.

Kuniholm MH, Purcell RH, McQuillan GM, Emgle RE, Wasley A, Nelson KE. 2009. Prevalence of hepatitis E virus infections in the United States: Data from NHANES III, 1988-1994. J Infect Dis 200: 48-56.

Labrique AB, Zaman K, Hossain Z, Saha P, Yunus M, Hossain A, Ticehurst J, Nelson KE. 2009. Population seroprevalence of hepatitis $\mathrm{E}$ virus antibodies in rural Bangladesh. Am J Trop Med Hyg 81: 875-881.

Labrique AB, Kuniholm MH, Nelson KE. 2010a. The global impact of hepatitis E: New horizons for an emerging virus. In Emerging infections (ed. Scheld WM, Grayson ML, Hughes JM), Vol. 9, pp. 53-93. ASM, Washington, DC.

Labrique AB, Zaman K, Hossain Z, Saha P, Yunus M, Hossain A, Ticehurst JR, Nelson KE. 2010b. Epidemiology and risk factors of incident hepatitis $\mathrm{E}$ virus infection in rural Bangladesh. Am J Epidemiol 172: 952-961.

Labrique AB, Sikder SS, Krain LJ, West KP, Christian P, Rashid M, Nelson KE. 2012. Hepatitis E, a vaccinepreventable cause of maternal deaths. Emerg Infect Dis 18: 1401-1404.

Labrique AB, Zaman K, Hossain Z, Saha P, Yunus M, Hossain A, Ticehurst J, Kmush B, Nelson KE. 2013. An exploratory case control study of risk factors for hepatitis $\mathrm{E}$ in rural Bangladesh. PLoS ONE 8: e61351.

Lachish T, Erez O, Daudi N, Shouval D, Schwartz E. 2015 Acute hepatitis E virus in pregnant women in Israel and in other industrialized countries. J Clin Virol 73: 20-24.

Lee GH, Tan BH, Chi-Yuan Teo E, Lim SG, Dan YY, Wee A, Aw PP, Zhu Y, Hibberd ML, Tan CK, et al. 2016. Chronic infection with camelid hepatitis $\mathrm{E}$ virus in a liver transplant recipient who regularly consumes camel meat and milk. Gastroenterology 150: 7.e3.

Lopes T, Cable R, Pistorius C, Maponga T, Ijaz S, Preiser W Tedder R, Andersson MI. 2017. Racial differences in seroprevalence of HAV and HEV in blood donors in the Western Cape, South Africa: A clue to the predominant HEV genotype? Epidemiol Infect 145: 1910-1912.

Maila HT, Bowyer SM, Swanepoel R. 2004. Identification of a new strain of hepatitis E virus from an outbreak in Namibia in 1995. J Gen Virol 85: 89-95.

McDonald S. 1908. Acute yellow atrophy of the liver. Edin Med J 1: 83-88.

Mishra A, Saigal S, Gupta R, Sarin SK. 1999. Acute pancreatitis associated with viral hepatitis: a report of six cases with review of literature. Am J Gastroenterol 94: 22922295.

Mosley JW, Redeker AG, Feinstone SM, Purcell RH. 1977. Mutliple hepatitis viruses in multiple attacks of acute viral hepatitis. N Engl J Med 296: 75-78.

Naidu SS, Viswanathan R. 1957. Infectious hepatitis in pregnancy during Delhi epidemic. Indian J Med Res 45: 7176.

Naik SR, Aggarwal R, Salunke PN, Mehrotra NN. 1992. A large waterborne viral hepatitis E epidemic in Kanpur, India. Bull World Health Organ 70: 597-604.

Nelson KE, Shih JW, Zhang J, Zhao Q, Xia N, Ticehurst JR, Labrique AB. 2014. Hepatitis E vaccine to prevent morbidity and mortality during epidemics. Open Forum Infect Dis 1: ofu098.
Nelson KE, Heaney CD, Labrique AB, Kmush BL, Krain LJ. 2016. Hepatitis E: Prevention and treatment. Curr Opin Infect Dis 29: 478-485.

Nicand E, Armstrong GL, Enouf V, Guthmann JP, Guerin JP, Caron M, Nizou JY, Andraghetti R. 2005. Genetic heterogeneity of hepatitis E virus in Darfur, Sudan, and neighboring Chad. J Med Virol 77: 519-521.

Pal R, Aggarwal R, Naik SR, Das V, Das S, Naik S. 2005. Immunological alterations in pregnant women with acute hepatitis E. J Gastroenterol Hepatol 20: 1094-1101.

Patra S, Kumar A, Trivedi SS, Puri M, Sarin SK. 2007. Maternal and fetal outcomes in pregnant women with acute hepatitis E virus infection. Ann Intern Med 147: 28-33.

Rein DB, Stevens G, Theaker J, Wittenborn JS, Wiersma ST. 2012. The global burden of hepatitis E virus. Hepatology 55: 988-997.

Robinson DP, Klein SL. 2012. Pregnancy and pregnancyassociated hormones alter immune responses and disease pathogenesis. Horm Behav 62: 263-271.

Romagnani S. 1997. The Th1/Th2 paradigm. Immunol Today 18: 263-266.

Saravanabalaji S, Tripathy AS, Dhoot RR, Chadha MS, Kakrani AL, Arankalle VA. 2009. Viral load, antibody titers and recombinant open reading frame 2 protein-induced $\mathrm{T}_{\mathrm{H}} 1 / \mathrm{T}_{\mathrm{H}} 2$ cytokines and cellular immune responses in self-limiting and fulminant hepatitis E. Intervirology 52: 78-85.

Sazzad HMS, Labrique AB, Teo C, Luby SP, Gurley ES. 2017. Surveillance at private laboratories identifies small outbreaks of hepatitis E in urban Bangladesh. Am J Trop Med Hyg 96: 395-399.

Shah R, Nahar Q, Gurley ES. 2016. One in five maternal deaths in Bangladesh associated with acute jaundice: Results from a National Maternal Mortality Survey. Am J Trop Med Hyg 94: 695-697.

Shrestha MP, Scott RM, Joshi DM, Mammen MP, Thapa GB, Thapa N, Myint KS, Fourneau M, Kuschner RA, Shrestha SK, et al. 2007. Safety and efficacy of a recombinant hepatitis E vaccine. N Engl J Med 356: 895-903.

Smith AM, Lingas EO, Rahman M. 2000. Contamination of drinking water by arsenic in Bangladesh: A public health emergency. Bull World Health Organ 78: 10931103.

Smith DB, Simmonds P, Jameel S, Emerson SU, Harrison TJ, Meng X, Okamoto H, Van der Poel, Wim HM, Purdy MA. 2014. Consensus proposals for classification of the family Hepeviridae. J Gen Virol 95: 2223-2232.

Stanaway JD, Flaxman AD, Naghavi M, Fitzmaurice C, Vos T, Abubakar I, Abu-Raddad LJ, Assadi R, Bhala N, Cowie B, et al. 2016. The global burden of viral hepatitis from 1990 to 2013: Findings from the Global Burden of Disease Study 2013. Lancet 388: 1081-1088.

Stoszek SK, Abdel-Hamid M, Saleh DA, El Kafrawy S, Narooz S, Hawash Y, Shebl FM, El Daly M, Said A, Kassem E, et al. 2006a. High prevalence of hepatitis $\mathrm{E}$ antibodies in pregnant Egyptian women. Trans $\mathrm{R}$ Soc Trop Med Hyg 100: $95-101$.

Stoszek SK, Engle RE, Abdel-Hamid M, Mikhail N, AbdelAziz F, Medhat A, Fix AD, Emerson SU, Purcell RH Strickland GT. 2006b. Hepatitis E antibody seroconver- 
sion without disease in highly endemic rural Egyptian communities. Trans $R$ Soc Trop Med Hyg 100: 89-94.

Tam AW, Smith MM, Guerra ME, Huang CC, Bradley DW, Fry KE, Reyes GR. 1991. Hepatitis E virus (HEV): Molecular cloning and sequencing of the full-length viral genome. Virology 185: 120-131.

Teo CG. 2012. Fatal outbreaks of jaundice in pregnancy and the epidemic history of hepatitis E. Epidemiol Infect 140: 767-787.

Teshale EH, Howard CM, Grytdal SP, Handzel TR, Barry V, Kamili S, Drobeniuc J, Okware S, Downing R, Tappero JW, et al. 2010. Hepatitis E epidemic, Uganda. Emerg Infect Dis 16: 126-129.

van den Berg B, van der Eijk AA, Pas SD, Hunter JG, Madden RG, Tio-Gillen A, Dalton HR, Jacobs BC. 2014. Guillain-Barre syndrome associated with preceding hepatitis E virus infection. Neurology 82: 491-497.

Velazquez O, Stetler HC, Avila C, Ornelas G, Alvarez C, Hadler SC, Bradley DW, Sepulveda J. 1990. Epidemic transmission of enterically transmitted non-A, non-B hepatitis in Mexico, 1986-1987. JAMA 263: 3281-3285.

Viswanathan R. 1957. Infectious hepatitis in Delhi (195556): A critical study-Epidemiology. Natl Med J India 26: 362-377.
Epidemiology of Genotype 1 and 2 HEV Infections

Wang HY. 1989. Investigation of an outbreak of HNANB[E] in Shufu County, Xinjiang. Zhonghua Liu Xing Bing Xue Za Zhi 10: 270-273.

Wong DC, Purcell RH, Sreenivasan MA, Prasad SR, Pavri KM. 1980. Epidemic and endemic hepatitis in India: Evidence for a non-A, non-B hepatitis virus aetiology. Lancet 2: 876-879.

Wong LFA, Shallow H, O'Connell MP. 2008. Comparative study on the outcome of obstetric cholestasis. J Matern Fetal Neonatal Med 21: 327-330.

Zaaijer HL, Kok M, Lelie PN, Timmerman RJ, Chau K, van der Pal HJ. 1993. Hepatitis E in The Netherlands: Imported and endemic. Lancet 341: 826.

Zhang J, Zhang XF, Huang SJ, Wu T, Hu YM, Wang ZZ, Wang H, Jiang HM, Wang YJ, Yan Q, et al. 2015. Longterm efficacy of a hepatitis E vaccine. $N$ Engl J Med 372 914-922.

Zhu FC, Zhang J, Zhang XF, Zhou C, Wang ZZ, Huang SJ, Wang H, Yang CL, Jiang HM, Cai JP, et al. 2010 Efficacy and safety of a recombinant hepatitis $\mathrm{E}$ vaccine in healthy adults: A large-scale, randomised, doubleblind placebo-controlled, phase 3 trial. Lancet 376: 895-902. 


\section{$\&_{\mathrm{CSH}}^{\infty} \&$ Cold Spring Harbor

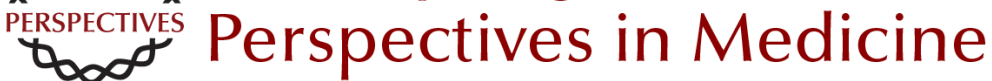

\section{Epidemiology of Genotype 1 and 2 Hepatitis E Virus Infections}

Kenrad E. Nelson, Alain B. Labrique and Brittany L. Kmush

Cold Spring Harb Perspect Med 2019; doi: 10.1101/cshperspect.a031732 originally published online May 7, 2018

\section{Subject Collection Enteric Hepatitis Viruses}

Hepatitis A Virus Genome Organization and Replication Strategy

Kevin L. McKnight and Stanley M. Lemon

Adaptive Immune Responses in Hepatitis A Virus and Hepatitis E Virus Infections

Christopher M. Walker

Small Animal Models of Hepatitis E Virus Infection Tian-Cheng Li and Takaji Wakita

Acute and Persistent Hepatitis E Virus Genotype 3 and 4 Infection: Clinical Features, Pathogenesis, and Treatment Nassim Kamar and Sven Pischke

Epidemiology of Genotype 1 and 2 Hepatitis E Virus Infections

Kenrad E. Nelson, Alain B. Labrique and Brittany L. Kmush

History of the Discovery of Hepatitis A Virus Stephen M. Feinstone

Epidemiology and Transmission of Hepatitis A Virus and Hepatitis E Virus Infections in the United States

Megan G. Hofmeister, Monique A. Foster and Eyasu $\mathrm{H}$. Teshale

Stem Cell-Derived Culture Models of Hepatitis E Virus Infection

Viet Loan Dao Thi, Xianfang Wu and Charles $M$. Rice
Evolutionary Origins of Enteric Hepatitis Viruses Anna-Lena Sander, Victor Max Corman, Alexander N. Lukashev, et al.

Enterically Transmitted Non-A, Non-B Hepatitis and the Discovery of Hepatitis E Virus

Stanley M. Lemon and Christopher M. Walker

Natural History, Clinical Manifestations, and

Pathogenesis of Hepatitis E Virus Genotype 1 and

2 Infections

Rakesh Aggarwal and Amit Goel

Hepatitis A Virus and Hepatitis E Virus: Emerging and Re-Emerging Enterically Transmitted

Hepatitis Viruses

Stanley M. Lemon and Christopher M. Walker

Hepatitis A Virus Capsid Structure

David I. Stuart, Jingshan Ren, Xiangxi Wang, et al.

Comparative Pathology of Hepatitis A Virus and Hepatitis E Virus Infection John M. Cullen and Stanley M. Lemon

Innate Immunity to Enteric Hepatitis Viruses Zongdi Feng and Stanley M. Lemon

Nonhuman Primate Models of Hepatitis A Virus and Hepatitis E Virus Infections

Robert E. Lanford, Christopher M. Walker and

Stanley M. Lemon

For additional articles in this collection, see http://perspectivesinmedicine.cshlp.org/cgi/collection/ 